\title{
Communication Locus of Causality Measures for Adolescents Who Stutter: A Preliminary Study
}

\author{
Kyungjae Lee \\ Department of Audiology and Speech-Language Pathology, Catholic University of Daegu, Gyeongsan, Korea
}

\author{
Correspondence: Kyungjae Lee, $\mathrm{PhD}$ \\ Department of Audiology and Speech-Language \\ Pathology, Catholic University of Daegu, 13-13 \\ Hayang-ro, Hayang-eup, Gyeongsan 38430, Korea \\ Tel: +82-53-850-2543 \\ Fax: +82-53-359-6780 \\ E-mail: kjlee0119@cu.ac.kr
}

Received: April 5, 2017

Revised: May 17, 2017

Accepted: May 22, 2017

This work was supported by the Ministry of Education of the Republic of Korea and the National Research Foundation of Korea (NRF2015S1A5A8017349).

\begin{abstract}
Objectives: It may be difficult to provide appropriate treatment for adolescents who stutter (AWS) due to their academic, physical, and psychological features. Additionally, there are limited assessment tools for AWS in Korea. Accordingly, the primary purpose of the current study was to develop questionnaire-type locus of causality measures for AWS and compare locus of causality and other features of AWS and adolescents who do not stutter (AWNS). Methods: A questionnaire type measure of communication related locus of causality measure was developed and conducted for a total of 18 AWS and AWNS individuals. In addition, content analysis of freely written material was conducted to determine communication related and general locus of causality. Moreover, other measures of stuttering, such as communication attitude tests, were conducted, and relationships among these measures were determined. Results: AWS showed higher Origin and Pawn scores than AWNS, as determined by the questionnaire-type communication locus of causality measure. Communication-related Pawn scores of AWS, based on content analysis, were higher than those of AWNS and there were significant relationships among questionnaire-type locus of causality measure scores and other stuttering measure scores. Conclusion: The results showed the questionnaire-type locus of causality measures were reliable and valid indicator of AWS. Even though AWS may show similar characteristics to adults who stutter, clinicians should try to measure various dimensions of the disorder in order to provide appropriate treatment.
\end{abstract}

Keywords: Stuttering, Adolescents who stutter, Origin, Pawn, Locus of causality
말더듬은 말의 비유창성이 가장 큰 특성이나 다른 다양한 영역 에서도 부정적인 영향을 미칠 수 있는 다면적인 장애이다(Guitar, 2013). 말더듬는 사람은 일반인들과 비교해서 더 많은 수의, 그리고 질적으로 다른 비유창성을 말에서 보이며, 말더듬을 회피하거나 탈출하기 위한 행동을 보일 수 있다. 또한 말더듬에 대해서 주위의 부정적인 반응을 반복적으로 경험하다 보면 자기 자신의 말과 말 더듬에 대해서 부정적인 감정과 태도를 말더듬는 사람은 발전시킬 수 있다. 이와 같은 말더듬의 다면적인 특성은 ICF에서 제시하는 장애의 정의에도 잘 적용될 수 있는데(Yaruss \& Quesal, 2004), 이 러한 설명은 말더듬을 효율적으로 평가하고 치료하기 위해서는 다 양한 측면을 목표로 해야 한다는 점을 강조한다(Manning, 2010).

말더듬의 여러 다면적인 영역 중 특히 내면적인 특성은 치료효과
의 유지 측면에서도 중요하다(Craig, Franklin, \& Andrews, 1984; DiLollo, Neimeyer, \& Manning, 2002; Manning, 2010). 말더듬의 외적 특성은 전술한 말의 비유창성일 수 있으며, 내적 특성은 일반 적으로 심리적, 인지적 특성과 같은 대상자의 “보이지 않는" 특성 을 의미한다. 예를 들어 말더듬는 사람은 두려움, 불안, 걱정 등과 같은 부정적인 감정을 보일 수 있는데, 이러한 감정은 반복적인 말 더듬 경험의 결과일 것으로 생각된다(Manning, 2010). 이러한 부 정적인 감정뿐 아니라 말더듬는 사람은 자신의 말과 말더듬에 대 해서 부정적인 태도와 인지적인 반응을 보일 수 있다. 이와 관련하 여 말더듬는 사람은 치료를 통하여 유창성의 증진을 보일 수 있으 나치료 종료 이후에 다시 비유창성이 나타나는, 즉 치료 후 재발이 매우 빈번히 나타난다고 한다(Manning, 2010). 이러한 치료 후 재 
발과 관련된 요인으로 유창성 증진과 더불어 의사소통태도의 개 선, 통제소의 변화와 같은 내적 특성의 변화가 제시되었다(Craig et al., 1984).

치료 후 재발과 관련있다고 제시된 통제소(locus of control)와 더 불어 최근에는 이와 유사한 구성요소인 인과소(locus of causality) 가 치료 중 변화를 민감하게 나타내는 지표로 제시되었다(Lee, Manning, \& Herder, 2011, 2015). 통제소란 자신의 행동에 대한 강화물 의 위치에 대한 믿음으로 크게 내적 통제소와 외적 통제소로 구분 된다(Rotter, 1966). 내적 통제소란 자신의 행동의 강화물이 자기 자 신에게 있다고, 외적 통제소란 외부의 요인이 자신의 행동의 강화 물이 된다는 믿음이다. 말더듬는 사람은 일반인과 비교, 외적 통제 소를 보이고 있다고 보고되었으며, 치료를 통하여 외적 통제소에서 내적 통제소로의 변화를 보인 사람들이 그러한 변화를 보이지 않 은 사람보다 치료 종료 후에도 유창성의 유지가 잘 되는 것으로 보 고되었다(Craig et al., 1984). 이와 관련하여 인과소는 자신의 행동 의 원인이자기자신 혹은 외부에 있는지에 대한 믿음이다(DeCharms, 1968). De Charms (1968)에 따르면 자기 자신이 스스로 원해서 행 동을 하거나 혹은 자기 자신이 행동의 원인이라고 믿는 경우를 오 리진(origin)이라고 하며, 이와는 달리 우연히 혹은 외부 등의 영향 으로 인해 행동을 하게 되었다고 믿는 것을 폰(pawn)이라고 한다. 특히 의사소통과 관련된 부담감 등을 지칭하는 용어인 의사소통 태도와는 달리 인과소는 행동 원인에 대한 인식과 관련된 개념이기 에 행동의 변화에 더 민감할 수 있으며, 단순히 긍정적, 부정적으로 이분화될 수 없다. 즉 인과소는 단순히 말을 더듬었는지 아니면 더 듬지 않았는지, 혹은 태도가 긍정적인지 부정적인지 측정하는 것 이 아니라 특정 행동을 하게 된 이유가 스스로 원해서인지 아니면 어쩔 수 없어서, 혹은 외부의 영향으로 하게 되었는지와 관련된 인 식을 측정한다. 이와 관련하여 말더듬성인을 대상으로 집중치료를 실시한 후 이들의 인과소 변화를 살펴본 결과, 이들은 치료 중 오리 진의 증가와 폰의 감소를 보였다(Lee et al., 2011). 그 결과, 치료 후 에는 말더듬성인은 일반인과 유사한 폰 성향, 그리고 일반인보다 높은 오리진 성향을 보였다.

이러한 결과는 인과소를 측정하는 것이 말더듬성인이 치료 중 보일 수 있는 내재적인 특성을 민감하게 나타낼 수 있다는 점을 시 사하나 분석의 어려움으로 인하여 실제 임상현장에서는 적용이 어 려울 수 있었다. 이전 연구에서는 대상자가 자유롭게 작성한 글의 내용을 분석하여 대상자가 보이는 오리진 성향과 폰 성향을 분석 하였다. 이와 같은 글 내용의 내용분석은 대상자의 심리적 특성을 타당하고도 신뢰롭게 나타낸다는 장점이 있다(Lee et al., 2011, 2015; Shin \& Lee, 2013). 이와 더불어 인과소는 대상자의 특성을 오리진
과 폰, 두 가지 양상으로 측정하기에 지금까지 말더듬연구에서 쓰 였던 통제소 평가도구와는 달리 말더듬는 사람의 다양한 특성을 보다 민감하게 나타낼 수 있었다. 예를 들어 말더듬성인은 치료를 통하여 전체적으로는 오리진의 향상, 폰의 감소를 보였으나 이와 더불어 오리진의 향상 없는 폰의 감소, 폰의 변화 없이 오리진의 향 상만 보인 경우, 오리진 감소와 폰 증가 등 다양한 변화의 양상을 나 타내었다(Lee et al., 2011, 2015). 즉 통제소와는 달리 인과소 평가도 구는 오리진과 폰 이라는 두 가지 측면에서 대상자의 특성을 측정하 기에 말더듬과 같이 각 개인에 따라서 다른 특성을 보이는 장애군 에서 특히 더 효용성이 높을 수 있을 것이다. 하지만 이전 연구에서 사용하였던 인과소 평가도구는 우선 연구자가 대상자의 말이나 글 을 전사한 후 그 내용을 판단하여 분석하였기에 시간도 오래 걸리 고 신뢰롭게 분석하기 위해서는 훈련이 필요하였다. 이에 임상에서 사용하기에 상대적으로 간편한 인과소 평가도구가 개발된다면 치 료 중 변화를 대상자와 치료사 모두 적절히 측정할 수 있을 것이며, 이를 통하여 치료의 방향성이 보다 적절히 조절될 수 있을 것이다.

인과소가 말더듬성인의 변화를 민감하게 나타낼 수 있다고 보고 되었기에 말더듬청소년의 특성과 치료 중 변화 역시 인과소 관련 평가도구가 적절히 나타낼 것으로 기대되나 아직 이와 관련된 실증 적인 연구는 부족한 편이다. 말더듬의 평가 및 치료는 각 대상자에 따라 개별적으로 진행될 수 있으나 크게 연령대에 따라 그 특성이 구분된다. 예를 들어 학령전기 말더듬아동의 경우에는 아동의 부 모가 평가 및 치료에서 중요한 역할을 담당하며, 성인의 경우에는 대상자 자신이 치료 중 변화의 주된 요인이 된다(Guitar \& McCauley, 2010). 특히 최근에는 말더듬청소년, 혹은 학령기아동이 학교에 서 겪을 수 있는 놀림과 괴롭힘 등에 대한 관심이 높아졌는데, 이는 이러한 시기의 경험으로 인하여 이후 성인시기의 사회적 활동에 제 약을 받을 수 있을 것이기 때문이다. 예를 들어 말더듬아동은 일반 아동보다 괴롭힘을 당할 가능성이 더 높으며, 영국 학령기 말더듬 아동 중 $80 \%$ 이상이 학교에서 괴롭힘을 경험하였다고 한다(Blood \& Blood, 2004; Hugh-Jones \& Smith, 1999). 이러한 놀림과 괴롭힘 이외에도 의사소통에 대한 두려움과 회피 등으로 인하여 수업 참 여 등을 회피하여 학업수행에도 어려움으로 보일 수 있으며, 이러 한 경험 등으로 인하여 성인 시기에는 직업 선택의 제한등을 겪을수 있다(McAllister, Collier, \& Shepstone, 2012; O’Brian, Jones, Packman, Menzies, \& Onslow, 2011; Williams, Melrose, \& Woods, 1969). 이러한 어려움들을 말더듬청소년은 겪을 수 있지만 대상자 자신이 “청소년”이기에 가지는 여러 학업적, 심리적, 신체적 특성들로 인하 여 말더듬치료가 특히 어려울 수 있을 것이다(Manning, 2010). 하 지만 국내에서 이들을 대상으로 하는 연구는 매우 부족한 편이다. 
예를 들어서 2000년대 초반 10년간의 말더듬연구 동향을 조사한 Shin, Chon과 Lee (2009)에 따르면 가장 많은 연구의 대상이 성인 및 청소년이라고 하였으나 그 중 청소년의 비중이 어느 정도였는지 는 정확하게 밝히고 있지 않다. 더불어 Lee, Lee, Sim과 Oh (2016) 는 말더듬청소년을 대상으로 괴롭힘과 관련된 질적 연구를 실시하 였는데, 이들에 따르면 말더듬청소년은 괴롭힘에 대해 의존-수동 적 대처를 하였다고 한다. 또한 청소년만을 대상으로 이들의 특성 을 전문적으로 평가하는 말더듬 평가도구 역시 국내에서는 매우 부족한 편이다. 국내에서 말더듬는 사람을 대상으로 가장 널리 사 용되고 있는 평가도구로는 파라다이스-유창성 검사-II (ParadiseFluency Assessment-II, P-FA-II; Sim, Shin, \& Lee, 2010)가 있으나 이는 학령전기 아동, 초등학생, 중학생 이상으로 연령대를 구분하 여 시행되고 있으며, 청소년과 성인을 하나의 기준을 사용하여 평 가하고 있다. 이에 본 연구에서는 말더듬청소년을 대상으로 보다 간편하게 임상에서 사용할 수 있는 설문지 형식의 인과소 평가도 구를 개발하고 이러한 평가도구의 타당도와 일관성을 살펴보는 것 을 목적으로 하였다. 전술하였듯이 내용분석을 이용한 인과소 측 정은 대상자의 변화를 민감하게 나타낼 수 있다고 보고되었으나 임상에서 사용하기에는 어려움이 따를 수 있기 때문이다. 더불어 해외에서도 말더듬청소년을 대상으로 한 인과소 관련 연구는 매우 부족한 편이며, 단지 일반 학령기 아동 혹은 청소년을 대상으로 전 술하였던 내용분석을 이용한 인과소 측정연구만이 있을 뿐이었다 (De Charms, 1968; Plimpton \& De Charms, 1976). 비록 말더듬청 소년의 치료가 상대적으로 어렵다고는 하나 말더듬청소년의 치료 중 나타날 수 있는 변화를 본 연구에서 의도하는 민감한 평가도구 를 이용하여 적절히 나타낸다면 치료 동기 및 치료 중 변화를 보다 효율적으로 촉진시킬 수 있을 것으로 기대된다. 또한 본 연구에서 는 인과소 평가도구의 개발과 더불어 기존 평가도구 및 새로 개발 한 평가도구 등을 사용하여 말더듬청소년의 특성을 일반청소년과 비교하고자 하였다.

\section{연구방법}

\section{연구대상}

본 연구에서는 총 9명의 말더듬청소년(평균연령 14.3세, 범위: 12-16세)과 9명의 일반청소년(평균연령: 14.6세, 범위: 12-16세), 총 18 명을 대상으로 인과소를 측정하여 비교한 자료를 보고하였다. 이들은 모두 남학생이었으며, 중학생이 10 명, 고등학생이 8 명이었 다. 말더듬청소년은 언어치료사가 말더듬이라고 진단하였으며, 이 들의 말더듬 중증도는 P-FA-II (Sim et al., 2010) 평가 결과, 약함 2
명, 중간 3 명, 심함 4 명이었다. 이들은 본 연구에 참여 당시, 말더듬 치료를 받고 있었으나, 과거 말더듬치료경험은 통제되지 않았다. 일 반청소년의 경우 자신이 말더듬는 사람이라고 생각하지 않는다고 자기보고 하였으며, 말에서 말더듬과 관련된 특이사항이 관찰되지 않았다. 참여자 모두 인지, 행동, 심리 등과 같은 문제는 없다고 보 고하였다.

\section{평가도구 및 실험방법}

\section{의사소통 인과소 평가도구}

기초문항선정

우선 본 연구의 연구자는 말더듬관련 국내외의 평가도구, 인과 소 및 통제소 관련 연구, 말더듬특성 등의 자료 등을 검토하여 말더 듬의 원인, 말더듬, 의사소통 등과 관련하여 말더듬청소년의 의사 소통 관련 인과소를 적절히 나타낼 수 있다고 생각되는 총 36항목 을 선정하였다. 이러한 36 개 항목 중 18 개의 항목은 오리진 특성을, 18 개의 항목은 폰을 나타내는 항목으로 구성하였다.

타당도와 일관성 측정

위와 같은 방식으로 구성된 문항이 말더듬청소년의 인과소 특성 을 적절히 나타내는지 명목타당도를 측정하기 위하여 네 명의 말더 듬 관련 전문가에게 이를 평가하게 하였다. 이들은 모두 언어치료 관련 석사 혹은 박사 소지자로서 말더듬 관련 치료 및 연구경험이 5년 이상인 사람들이었다. 이들의 의견을 바탕으로 전체적으로 항 목을 수정하고 타당도 점수가 낮은 총 16 개의 항목을 삭제하여 오 리진 항목 10 개, 폰 항목 10 개 등 총 20 개 항목으로 검사지를 구성 하였다. 이렇게 구성된 20 개 항목을 대상으로 5 점 척도(1점: 매우 적 절하지 않음, 5 점: 매우 적절함)로 타당도를 측정한 결과, 평균 4.61 $(\mathrm{SD}=.76)$ 로 검사도구는 적절한 타당도를 나타내었다.

본 연구에서는 우선 위와 같은 방식으로 구성된 20 개 항목의 의 사소통 인과소 평가도구를 사용하여 대상자의 인과소를 평가하였 다. 말더듬청소년과 일반청소년의 자료를 대상으로 크론바흐 알파 로 내적 일관성을 측정한 후 일관성이 낮거나 두 집단 사이에 차이 가 적은 오리진 관련 세 항목과 폰 관련 세 항목을 삭제하였다. 이렇 게 구성된 총 14 항목을 대상으로 측정한 크론바흐 알파는 803 이었 다. 상대적으로 적은 문항수와 참여자 수를 고려한다면 14항목으 로 이루어진 의사소통 관련 인과소 평가도구는 적절한 신뢰도를 보 인다고 할수 있다.

최종평가도구

본 연구에서 사용한 의사소통 인과소 평가도구는 총 14 항목으 
로 구성되었다(Appendix 1). 총 14항목 중 오리진 관련 항목은 2,3, $7,11,12,13,14$ 번 항목 등 총 일곱 항목이며, 폰 관련 항목 역시 일 곱 항목으로 $1,4,5,6,8,9,10$ 번 항목이다.

\section{기타 말더듬특성 평가도구}

본 연구에서는 지금까지 말더듬성인을 대상으로 인과소를 측정 하는데 사용되었던 오리진-폰 분석도구, 인과소와 유사한 구성요 소인 통제소를 측정하는 평가도구인 행동통제소검사, 그리고 전반 적인 말더듬청소년의 의사소통태도를 측정하는 평가도구인 P-FAII 의사소통태도 평가를 사용하여 말더듬청소년과 일반청소년의 특성을 측정하여 비교하였다. 또한 이러한 결과를 본 연구에서 개 발한 의사소통 인과소 평가도구와 비교하여 의사소통 인과소 평가 도구의 타당도를 평가하였다.

우선 연구자는 오리진-폰 분석도구(The Origin and Pawn Scales; Westbrook \& Viney, 1980)를 사용하여 대상자의 의사소통 관련 인과소와 일반적인 상황에서의 인과소를 측정하였다. 오리진-폰 분석도구는 대상자가 자유롭게 작성한 글 자료 중에서 대상자의 오리진과 폰을 나타내는 절의 수를 바탕으로 오리진 점수와 폰 점 수를 측정하는 검사도구이다. 이전 연구에서는 이와 같은 내용분 석을 사용한 오리진-폰 분석도구가 말더듬성인의 특성을 타당하 고도 민감하게 나타낸다고 보고되었다(Lee et al., 2011, 2015). 더불 어 의사소통과 일반적인 상황 관련 글쓰기를 분석한 오리진, 폰 점 수가 말더듬성인과 일반인 사이에 차이가 있을 수 있다고 보고되 었다(Shin, Lee, \& Jung, 2015).

이와 더불어 연구자는 인과소와 유사한 구성요소인 통제소를 측정하기 위하여 행동통제소검사(Locus of Control of Behavior, LCB; Craig et al., 1984)를 이용하였다. 행동통제소검사는 17항목 의 Likert 척도 검사로 말더듬성인의 통제소를 측정하는데 사용되 었다. 이전 연구에 따르면 치료를 통하여 외적 통제소에서 내적 통 제소로의 변화를 보인 말더듬성인은 통제소의 변화를 보이지 않은 성인보다 치료 중 변화를 치료 이후에도 유지하였다고 보고되었다 (Craig et al., 1984).

위 두 가지 인과소와 통제소 평가도구 이외에 P-FA-II의 의사소 통태도 평가를 이용하여 대상자의 의사소통태도를 측정하였다. PFA-II의 의사소통태도 평가는 총 30 항목으로 구성되었으며, 초등학 생, 중학생 이상의 두 연령대의 집단을 대상으로 사용이 가능하다.

\section{실험방법}

실험은 개별적으로 실시되었다. 평가도구는 의사소통 인과소 평 가도구, 행동통제소검사, 내용분석을 하기 위한 두 가지 종류의 글
쓰기, P-FA-II 의사소통태도 평가 순으로 실시되었다. 내용분석을 위한 글쓰기는 최근 의사소통 경험과 인생에서 가장 흥미로운 일 에 대해서 각 10 분씩 작성한 내용이며, 글의 주제, 내용, 표현 방법 등과 관련된 제약은 없었다. 두 가지 주제는 무순으로 제시되었다.

\section{분석방법}

\section{의사소통 인과소 평가도구 분석방법}

의사소통 인과소 평가도구는 총 세 가지의 방식으로 점수를 산 출하였다. 우선 오리진 성향을 나타내는 $2,3,7,11,12,13,14$ 번 항목 의 점수를 모두 더하여 오리진 점수를, 폰 성향을 나타내는 $1,4,5$, $6,8,9,10$ 번 항목의 점수를 모두 더하여 폰 점수를 산출하였다. 또 한 행동통제소검사의 측정방식과 유사하게 역채점방식을 사용한 총점을 산출하였다. 즉 총점을 측정하기 위해서는 우선 오리진 점 수를 나타내는 항목의 경우, 이를 역으로 측정하여 점수를 재산출 하였다. 이렇게 측정된 점수와 폰 관련 항목의 점수를 모두 합산하 여 의사소통 인과소 평가도구의 총점을 산출하였다. 이와 같이 의 사소통 인과소 평가도구의 점수를 세 가지 방식으로 산출한 이유 는 오리진과 폰이라는 두 가지 구성요소의 특성을 보다 민감하게 나타내고 이와 더불어 의사소통 인과소 평가도구의 결과를 다른 평가도구와의 직접적인 비교를 하기 위함이었다.

\section{일반적인 상황과 의사소통 관련 인과소 측정 방법}

글쓰기 자료를 이전 국내연구(Lee, 2013; Shin et al., 2015) 등에 서 제시된 분석방법을 따라 분석하여 오리진과 폰 점수를 측정하 였다. 특히 최근 의사소통 경험 글 자료를 분석하여 산출한 오리진 과 폰 점수를 각각 의사소통 관련 오리진 점수, 폰 점수로 산출하였 으며, 가장 흥미로윘던 일과 관련된 글 자료를 분석하여 일반적인 오리진 점수와 폰 점수를 산출하였다. 또한 두 상황에서의 각각의 오리진-폰 점수 비율을 산출하였다.

\section{타당도와 신뢰도 분석방법}

전술하였듯이 의사소통 인과소 평가도구의 명목타당도를 측정 하기 위하여 전문가를 대상으로 한 설문조사를 실시하였다. 더불 어 내적 일관성을 측정하기 위하여 크론바흐 알파를 측정하였다. 본 연구에서 측정한 의사소통 인과소 평가도구 결과, 내용분석을 통해 산출한 의사소통 관련, 그리고 일반적인 상황에서의 인과소 결과, 행동통제소검사 결과, P-FA-II 의사소통태도 평가 결과 등이 말더듬청소년과 일반청소년, 두 집단 사이에 차이가 나타나는지 독 립표본 $t$-검정을 실시하여 살펴보았다. 이를 통하여 본 연구에서 개 발한 의사소통 인과소 평가도구가 말더듬청소년과 일반청소년의 
차이를 민감하게 나타낼 수 있는지 살펴보았다. 마지막으로 말더듬 청소년의 의사소통 인과소 평가도구의 결과와 다른 평가도구 결과 와의 피어슨 상관관계 분석을 통하여 의사소통 인과소 평가도구의 타당도를 살펴보고자 하였다.

\section{연구결과}

\section{인과소 결과}

본 연구 참여자의 의사소통 인과소 평가도구, 글쓰기 내용을 오 리진-폰 분석도구를 사용하여 분석한 의사소통 관련 인과소와 일 반적인 상황에서의 인과소 결과, 행동통제소검사 결과, P-FA-II 의 사소통태도 평가 결과는 Table 1과 같다.

우선 의사소통 인과소 평가도구의 오리진 점수의 경우, 말더듬 청소년은 평균 15.9 점 $(\mathrm{SD}=6.6)$, 일반청소년은 8.8 점 $(\mathrm{SD}=4.0)$ 으로 말더듬청소년의 오리진 점수가 통계적으로 유의하게 일반청소년보 다 높았다 $(t(16)=2.770, p=.014)$. 더불어 말더듬청소년의 의사소 통 인과소 평가도구의 폰 점수는 16.7 점 $(\mathrm{SD}=4.7)$, 일반청소년은 7.3점 $(\mathrm{SD}=5.0)$ 이었으며, 두 집단의 차이는 통계적으로 유의하였다 $(t(16)=4.041, p<.001)$. 마지막으로 오리진 점수를 역으로 산출하 여 계산한 의사소통 인과소 평가도구의 총점은 말더듬청소년의 경 우 31.7점( $\mathrm{SD}=9.3)$, 일반청소년은 19.0점 $(\mathrm{SD}=4.9)$ 이었으며, 두 집 단의 차이는 통계적으로 유의하였다 $(t(16)=3.603, p=.002)$.

본 연구 참여자의 의사소통 상황 글쓰기를 분석하여 산출한 의사 소통 관련 오리진 점수의 경우 말더듬청소년은 평균 2.0 점 $(\mathrm{SD}=0.8)$, 일반청소년은 1.3 점 $(\mathrm{SD}=0.6)$ 으로 말더듬청소년이 조금 높은 경향
을 보였으나 이러한차이는 통계적으로 유의하지 않았다 $(t(16)=2.051$, $p=.057)$. 더불어 의사소통 관련 폰 점수의 경우 말더듬청소년은 2.3 점 $(\mathrm{SD}=0.4)$ 으로 일반청소년의 평균점수 1.5 점 $(\mathrm{SD}=0.4)$ 보다 유의하게 높은 수준을 보였다 $(t(16)=3.803, p=.002)$. 말더듬청소 년의 오리진-폰 점수비율은 평균 $86.2(\mathrm{SD}=26.5)$, 일반청소년은 $93.3(\mathrm{SD}=52.1)$ 으로 두 집단 사이에 통계적으로 유의한 차이는 없 었다 $(t(16)=-.865, p=.720)$.

마지막으로 일반적인 상황 글쓰기에서의 말더듬청소년의 오리진 점수는 1.6 점 $(\mathrm{SD}=0.6)$, 일반청소년의 오리진 점수는 1.2 점 $(\mathrm{SD}=0.8)$ 로 말더듬청소년의 오리진 점수가 높은 경향을 보였으나 이러한 차 이는 통계적으로 유의하지 않았다 $(t(16)=1.022, p=.322)$. 말더듬 청소년의 일반적인 상황에서의 폰 점수는 평균 1.6 점 $(\mathrm{SD}=0.4)$, 일 반청소년은 평균 1.3 점 $(\mathrm{SD}=0.4)$ 으로 말더듬청소년의 폰 점수가 높은 경향을 보였으나 이 역시 통계적으로 유의하지 않았다 $(t(16)=$ $1.727, p=.104)$. 마지막으로 일반적인 상황에서의 말더듬청소년의 오리진-폰 점수비율은 평균 $106.5(\mathrm{SD}=58.1)$, 일반청소년은 평균 $106.5(\mathrm{SD}=66.6)$ 으로 두 집단 사이의 차이는 통계적으로 유의하 지 않았다 $(t(16)=-.001, p=.999)$.

\section{집단에 따른 기타 말더듬 관련 평가도구 차이}

말더듬청소년의 행동통제소검사 평균점수는 40.3 점 $(\mathrm{SD}=9.0)$, 일반청소년의 평균점수는 34.7점( $\mathrm{SD}=9.0)$ 으로 말더듬청소년의 높은 경향을 보였으나 이러한 차이는 통계적으로 유의하지 않았다 $(t(16)=1.337, p=.200)$. P-FA-II 의사소통태도 평가 결과 말더듬청 소년은 평균 17.2점 $(\mathrm{SD}=7.8)$, 일반청소년은 7.3점 $(\mathrm{SD}=4.9)$ 으로 말

Table 1. Mean (SD) scores of communication locus of causality, the Origin and Pawn scales, locus of control of behavior, and P-FA-II communication attitude test of adolescents who do and do not stutter

\begin{tabular}{|c|c|c|c|}
\hline & Adolescents who stutter & Adolescents who do not stutter & $t$ \\
\hline \multicolumn{4}{|l|}{ Communication Locus of Causality } \\
\hline Origin scores & $15.9(6.6)$ & $8.8(4.0)$ & $2.770^{*}$ \\
\hline Pawn scores & $16.7(4.7)$ & $7.3(5.0)$ & $4.041^{* *}$ \\
\hline Total scores & $31.7(9.3)$ & $19.0(4.9)$ & $3.603^{*}$ \\
\hline \multicolumn{4}{|l|}{ The Origin and Pawn Scales } \\
\hline Communication-related Origin scores & $2.0(.8)$ & $1.3(0.6)$ & 2.051 \\
\hline Communication-related Pawn scores & $2.3(.4)$ & $1.5(0.4)$ & $3.803^{*}$ \\
\hline Communication-related Origin-Pawn scores ratio & $86.2(26.5)$ & $93.3(52.1)$ & -.865 \\
\hline General Origin scores & $1.6(.6)$ & $1.2(.8)$ & 1.022 \\
\hline General Pawn scores & $1.6(.4)$ & $1.3(.4)$ & 1.727 \\
\hline General Origin-Pawn scores ratio & $106.5(58.0)$ & $106.5(66.6)$ & -.001 \\
\hline Locus of Control of Behavior & $40.3(9.0)$ & $34.7(9.0)$ & 1.337 \\
\hline P-FA-II Communication Attitude Test & $17.2(7.8)$ & $7.3(4.9)$ & $3.224^{*}$ \\
\hline
\end{tabular}

P-FA-II=Paradise-Fluency Assessment-II (Sim, Shin, \& Lee, 2010).

${ }^{*} p<.05,{ }^{* *} p<.001$. 
Table 2. Significant correlations among communication locus of causality scores and other measures of stuttering

\begin{tabular}{cl}
\hline $\begin{array}{c}\text { Communication locus } \\
\text { of causality }\end{array}$ & \multicolumn{1}{c}{ Measures with significant correlations } \\
\hline Origin Scores & General Origin-Pawn Scores Ratio $(r=-.732, p=.025)$ \\
& P-FA Communication Attitude Test Scores $(r=.707, p=.033)$ \\
Pawn Scores & Locus of Control of Behavior Scores $(r=.748, p=.021)$ \\
& P-FA Communication Attitude Test Scores $(r=.855, p=.003)$ \\
Total Scores & Locus of Control of Behavior Scores $(r=.789, p=.012)$ \\
& P-FA Communication Attitude Test Scores $(r=.912, p=.001)$ \\
\hline
\end{tabular}

P-FA-II = Paradise-Fluency Assessment-II (Sim, Shin, \& Lee, 2010).

더듬청소년의 점수가 통계적으로 유의하게 더 높았다 $(t(16)=3.224$, $p=.005)$.

\section{의사소통 인과소 평가도구와 다른 도구와의 상관관계}

의사소통 인과소 평가도구와 유의한 상관관계를 보인 다른 평가 도구는 Table 2 와 같다. 우선 의사소통 인과소 평가도구의 오리진 점수는 일반적인 상황에서의 오리진-폰 점수비율과 높은 부적 상 관관계 $(r=-.732, p=.025)$ 를 나타내었다. 또한 의사소통 인과소 평 가도구의 폰 점수는 행동통제소 도구와 높은 양적 상관관계 $(r=.748$, $p=.021)$ 를 보였다. 의사소통 인과소 평가도구의 총점 역시 행동통 제소검사와 높은 양적 상관관계를 보였다 $(r=.789, p=.012)$. P-FA$\mathrm{II}$ 의 의사소통태도 평가는 의사소통 인과소 평가도구의 오리진 점 수 $(r=.707, p=.033)$, 폰 점수 $(r=.855, p=.003)$, 총점 $(r=.912, p=.001)$ 과 모두 높은 양적 상관관계를 보였다.

\section{논의 및 결론}

본 연구는 말더듬청소년을 대상으로 사용할 수 있는 상대적으 로 소수의 항목으로 이루어진 인과소 평가도구를 개발하는 것을 주요 목적으로 하였다. 더불어 글쓰기를 대상으로 측정한 인과소, 행동통제소, 의사소통태도 평가 결과 등이 말더듬청소년과 일반청 소년, 두 집단 사이에서 차이가 있는지 살펴보고, 한정된 항목으로 이루어진 의사소통 인과소 평가도구 결과와 어떠한 상관관계가 있 는지 살펴보았다. 비록 상대적으로 소수의 말더듬 중, 고등학생과 일반 중, 고등학생이 본 연구에 참여하였지만, 이들을 대상으로 실 시된 의사소통 인과소 평가도구 결과에서 통계적으로 유의한 차이 가 나타났다. 또한 말더듬청소년과 일반청소년은 글쓰기를 대상으 로 측정한 의사소통 관련 폰 점수, 의사소통태도 평가 결과 등에서 유의한 차이를 보였으며, 제한된 항목으로 이루어진 의사소통 인과 소 평가 결과는 행동통제소검사, 의사소통태도 평가 결과 등과 유
의한 상관관계를 보였다. 이를 좀 더 자세히 논의하면 다음과 같다.

\section{의사소통 인과소 평가도구의 신뢰도와 타당도}

상대적으로 소수의 항목으로 이루어진 의사소통 인과소 평가도 구 실시 결과, 본 연구의 말더듬청소년과 일반청소년 참여자 사이에 유의한 차이가 나타났는데, 이는 본 연구에서 사용한 인과소 평가 도구가 말더듬청소년의 특성을 민감하게 나타낼 수 있다는 점을 시 사한다. 본 연구에서 사용한 것과 같이 제한된 항목으로 대상자의 경험을 측정하는 평가도구의 단점은 대상자의 매우 다양한 경험을 적절히 나타내지 못할 수 있다는 것이다(Lee et al., 2011). 말더듬는 사람의 경험은 매우 다양하게 나타날 수 있기에 이러한 개별적이고 도 다양한 경험에 근거한 인과소를 측정하기 위하여 이전 연구에서 는 대상자가 자유롭게 작성한 글 자료를 대상으로 인과소를 나타 낸 문장의 수를 계산하여 인과소를 측정하였다(Lee et al., 2011, 2015). 이러한 내용분석이 대상자의 개별적이고도 다양한 경험을 타당하게 나타낼 수 있다고는 하지만 내용분석을 신뢰롭게 사용하 기 위해서는 분석자의 연습 혹은 훈련이 필요하기에 임상에서 활발 히 사용되기에는 제한점이 있었다. 이와 같은 제한점을 극복하기 위 하여 컴퓨터를 이용한 분석 등이 고려되고는 있으나(http://originandpawn.appspot.com 참조) 아직 국내에서는 이러한 연구가 부 족한 편이다. 이에 본 연구에서는 보다 간편하게 인과소를 측정하기 위하여 말더듬청소년의 말더듬에 대한 지식, 자신의 말과 말더듬에 대한 통제, 자신의 감정, 인식, 태도 등과 관련된 통제 등을 학교생 활, 친구관계, 일반적인 상황 등에서 살펴볼 수 있는 항목으로 설문 지를 구성하였으며, 이렇게 구성된 설문지 형식의 평가도구로도 말 더듬청소년과 일반청소년의 차이를 적절히 살펴볼 수 있었다.

특히 본 연구의 평가도구는 상대적으로 높은 내적 일관도를 보 였는데, 이는 말더듬청소년이 매우 다양하고도 개별적인 특성을 보 일 수 있으나 그와 동시에 공통적이거나 일반적인 특성을 본 연구 에서 사용한 의사소통 인과소 평가도구가 측정하였다는 점을 시사 한다. 일반적으로 설문지 형식의 평가도구의 내적 일관도는 평가항 목의 수가 증가할수록 높아지나 본 연구에서는 오리진 관련 항목 7 개, 폰 관련 항목 7 개 등 총 14 항목이라는 적은 수로 설문지를 구성 하였으나 내적 일과도는 상대적으로 높은 편이었다. 본 연구도구의 항목 수는 행동통제소검사의 17 항목, P-FA-II 의사소통태도 평가 의 30 항목 등과 비교하여 상대적으로 매우 적은 수의 항목이다. 더 불어 본 연구에는 말더듬청소년 9명, 일반청소년 9 명 등 총 18 명의 참여자만을 대상으로 검사를 실시하였는데도 불구하고 오리진 점 수, 폰 점수, 총 점수 등에서 두 집단 사이에 통계적으로 유의한 차 이가 나타났다. 이는 말더듬청소년이 일반적으로, 그리고 공통적 
으로 경험할 수 있는 인과소 관련 항목을 평가도구에 사용한 결과 일 것이다.

특히 본 연구에서 사용된 의사소통 인과소 평가도구는 다른 말 더듬특성 평가도구와 유의한 상관관계를 보였는데 이러한 결과는 본 연구의 의사소통 인과소 평가도구가 타당하였다는 점을 나타내 나이러한 해석에는 주의가 필요하다. 전술하였듯이 의사소통 인과 소 평가도구에서 측정한 오리진 점수, 폰 점수, 총 점수는 모두 PFA-II의 의사소통태도 평가 결과와 양적 상관관계를 보였으며, 이 와 더불어 폰 점수는 행동통제소검사 점수와 양적 상관관계를 보 였다. 폰은 자신의 행동의 원인이 자기 자신이 아니라 외부 환경, 운 등이라고 믿는 믿음이기에 외적 통제소와 유사한 구성요소일 수 있다. 이에 본 연구에서 행동통제소검사 결과와 폰이 유의한 양적 상관관계를 보인 것으로 추측된다. 이와 관련하여 해외 연구에서 도 폰 점수와 행동통제소검사 점수 사이에 양적 상관관계를 보고 하였다(Lee et al., 2011). 더불어 폰과 부정적인 의사소통태도와의 상관관계 역시 유사한 방식으로 해석될 수 있을 것이다. 반면 폰과 는 다른 특성으로 생각되는 오리진이 P-FA-II 의사소통태도 평가 와 양적 상관관계를 보인 것은 인과소의 다면적 특성과 치료 경험, 중증도 등과 같은 대상자의 개인적인 특성 등으로 인한 것으로 생 각되나 이와 관련된 추후 연구를 통하여 그 특성을 보다 면밀히 살 펴보는 것이 필요하다. 본 연구의 말더듬참여자들의 중증도는 약 함 2명, 중간 3 명, 심함 4 명 등으로 상대적으로 중증도가 심한 편이 었다. 더불어 이러한 말더듬 중증도 등으로 인하여 이들은 모두 치 료를 받고 있는 중이었다. 이와 관련하여 오리진으로 분류될 수 있 는 항목으로 본 연구에서는 본인의 노력이 필요하다는 점 등을 제 시하고 있는데, 본 연구의 말더듬참여자들은 치료과정에서 이와 같은 믿음이 커졌을 수 있다. 전술하였듯이 말더듬치료는 나이, 중 증도 등에 따라서 다양한 치료책략을 사용할 수 있으나 일반적으 로 말더듬성인을 대상으로 하는 말더듬치료는 유창성증진법과 말 더듬수정법으로 나뉜다. 비록 본 연구에 참여한 말더듬청소년이 어떠한 방식으로 치료를 받았는지 본 연구에서는 살펴보지 않았으 나 말더듬성인을 대상으로 하는 두 가지 치료책략은 대상자가 다 양한 기법 등을 사용해서 유창성을 향상시키는 것을 목적으로 하 거나말더듬을 자발적으로 수정할 수 있는 것을 목표로 한다. 즉 말 더듬청소년의 치료에서도 말더듬성인의 치료기법 등이 사용될 수 있기에 이와 같은 치료기법 혹은 과정의 습득을 통하여 본 연구의 말더듬청소년들은 높은 오리진 성향을 보였으며, 중증도 등이 심해 질수록 오래된 치료 경험으로 이러한 부정적인 의사소통태도와 오 리진 점수 사이에 양적 상관관계를 보인 것으로 생각될 수 있다. 이 에 후속연구에서는 말더듬치료 경험 등이 적거나 없는 대상자들을
대상으로 본 연구에서 사용한 평가도구의 타당성을 살펴보는 것이 필요할 것이다.

비록 본 연구에서 사용한 의사소통 인과소 평가도구의 신뢰도 와 타당도가 적절할 수 있지만 다음과 같은 점을 고려한 후속 연구 가 필요하다. 우선 평가도구의 분석 및 해석과 관련한 제한점이다. 이전 내용분석을 이용한 인과소 평가도구의 장점 중의 하나는 통 제소가 하나의 수치로 대상자의 단면적인 특성을 나타내는데 반하 여 인과소는 오리진과 폰이라는 두 가지 양상으로 대상자의 특성 을 나타낸다는 점이다. 이러한 인과소의 양면적인 특성으로 인하 여 오리진-폰 분석도구는 말더듬성인의 다양하고도 개별적인 특 성을 민감하게 나타낼 수 있었다(Lee et al., 2011, 2015). 본 연구에 서도 이와 같은 인과소 평가도구의 양면적인 특성을 유지하기 위하 여 오리진 점수와 폰 점수를 개별적으로 산출하였다. 이와 더불어 보다 단순한 지표를 생성해내기 위하여 폰 점수와 역으로 계산한 오리진 점수를 합한 총점을 산출하였다. 하지만 이와 같은 방식으 로 얻은 단순화된 총점을 낮은 경우는 오리진 성향을, 높은 수치는 폰 성향을 나타낸다고 해석하기에는 무리가 있다. 이와 관련하여 후속연구에서는 인과소와 같은 다면적인 특성을 보다 단순화하여 나타낼 수 있는 평가방식을 모색하는 것이 필요할 것이다.

\section{말더듬청소년의 인과소와 기타 내면적 특성}

본 연구에서 오리진-폰 분석도구를 사용하여 측정한 말더듬청 소년의 인과소 양상은 이전 연구의 말더듬성인의 인과소와 유사한 양상을 보였는데, 이는 말더듬청소년이 성인과 매우 유사한 말더듬 발전 양상을 보인다는 점을 시사한다. 전술하였듯이 의사소통과 관련된 글 자료를 분석하여 산출한 인과소의 경우, 말더듬청소년 은 일반청소년과 유사한 오리진 점수를 보였으나 폰 점수의 경우, 말더듬청소년의 폰 점수가 일반청소년보다 유의하게 높았다. 반면 일반적인 상황과 관련된 글 자료를 분석하여 산출한 오리진과 폰 점수에서는 두 집단의 차이가 통계적으로 유의하지 않았다. 이와 관련하여 국내와 해외의 말더듬성인 관련 연구 역시 유사한 결과 를 보고하고 있다. 예를 들어 미국 말더듬성인은 치료 전 측정한 오 리진 점수에서는 일반성인과 유사한 차이를 보이지 않으나 폰 점수 에서는 두 집단 사이에 유의한 차이가 나타났다고 보고되었다(Lee et al., 2011, 2015). 말더듬성인을 대상으로 한 국내연구 역시 본 연 구와 유사한, 이와 같은 양상을 보고하고 있다. 말더듬성인은 의사 소통과 관련된 오리진 점수에서는 일반성인과 차이를 보이지 않았 으나, 폰 점수에서는 유의한 차이를 보였다. 반면 일반적인 오리진 과 폰 점수에서는 두 집단 사이의 차이가 유의하지 않았다(Shin et al.. 2015). 이와 같은 결과는 의사소통 관련 높은 폰 성향이 말더듬 
청소년과 말더듬성인 등 말더듬는 사람을 나타내는 구별적인 특성 이 될 수 있음을 시사한다. 더불어 일반적인 상황에서의 폰 점수가 말더듬성인과 일반성인 사이에서 유의한 차이가 나타나지 않은 것 을 연구자는 말더듬성인이 느끼게 되는 부정적인 감정과 태도가 말더듬의 원인이 아니기 때문이라고 해석하였다(Shin et al., 2015). 이러한 해석은 본 연구의 말더듬청소년 참여자에게도 적용될 수 있을 것이다. 즉, 말더듬성인과 마찬가지로 말더듬청소년 역시 어렸 을 때부터의 반복적인 말더듬경험으로 인하여 의사소통과 관련하 여 부정적인 인식을 보일 수 있으나 아직 이러한 인식이 전반적인, 기질적인 특성으로 발전되지는 않았다는 것이다.

더불어 본 연구결과는 내용분석이 청소년에게도 적용될 수 있 다는 점을 시사한다. 내용분석은 전술하였듯이 글 자료 등에서 대 상자가 표현한 심리적 특성의 표현 횟수 등의 측정을 기본으로 한 다. 이에 내용분석을 적용하기 위해서는 특정 언어를 사용하는 데 어려움이 없어야 하며 모국어를 사용하지 않는 외국인 등에게는 사용이 제한되기도 하였다(Gottschalk \& Gleser, 1969). 본 연구의 참여자들은 성인이 아닌 청소년이었지만 이들이 작성한 글 자료를 대상으로 인과소를 측정한 결과, 말더듬성인과 유사한 특성이 나 타났기에 추후 연구에서도 역시 청소년을 대상으로 내용분석을 적 용할수 있을 것이다.

특히 본 연구에서 개발한 의사소통 인과소 평가도구의 결과, 말 더듬청소년이 일반청소년보다 더 높은 오리진 점수와 폰 점수를 보 였으나 내용분석을 이용한 인과소 평가에서는 의사소통 관련 폰 점수에서만 두 집단 간 유의한 차이를 보였다. 이러한 결과는 우선 본 연구의 참여자가 모두 치료를 받는 대상자일 수 있기에 나타난 결과일 수 있다. 치료를 받기 전의 말더듬성인은 높은 폰 점수가 큰 특징이나 성공적으로 집중치료를 받은 말더듬성인은 일반성인보 다 높은 오리진점수를 보였다(Lee et al., 2015). 이에 본 연구의 참여 자들은 모두 치료를 받는 중이었기에 치료 전 특성일 수 있는 높은 폰 성향과 치료 후 특성일 수 있는 높은 오리진 성향을 의사소통 인 과소 평가도구에서 모두 보였을 수 있다. 또한 말더듬청소년이 일반 청소년보다 의사소통에 더욱 민감하였기에 이와 같은 결과가 나타 났을 수 있다. 전술하였듯이 내용분석에서는 글 작성 내용이나 형 식에 제한을 두지 않기에 제한적인 시간에 대상자는 특징적으로 나타나는 성향만 나타낼 수 있는 글을 작성할 수 있다. 반면 본 연 구에서는 오리진 관련 항목과 폰 관련 항목의 수가 동등하도록 설 문지를 구성하였기에 대상자가 오리진과 폰, 두 가지 성향을 나타 낼 수 있는 기회가 모두 동등하게 있었다. 하지만 말더듬성인은 일 반적으로 의사소통에 대해서 일반인보다 더 민감할 수 있을 가능 성이 제시되었다(Lee et al.. 2015). 즉 의사소통에 대한 민감성 등으
로 인하여 오리진과 폰을 표현할 수 있는 동등한 기회가 주어졌을 때 일반 청소년보다 말더듬청소년들이 오리진과 폰 모두에서 더 높 은 점수를 보였을 것으로 추측된다.

본 연구에서는 행동통제소검사를 사용하여 말더듬청소년과 일 반청소년의 통제소를 이용하여 측정하였으나 두 집단 사이에 유의 한 차이가 나타나지 않았는데 이러한 결과는 보다 적절한 도구의 개발이 필요하다는 점을 시사한다. 우선 본 연구의 말더듬청소년과 일반청소년은 전체적으로 다소 높은 행동통제소 점수를 보였는데, 이는 아마도 청소년이라는 특성에 근거한 것으로 추측된다. 예를 들어 해외 말더듬성인의 행동통제소검사 평균 점수는 31 점이었으 며, 국내 말더듬성인의 행동통제소검사의 평균점수는 35점이었다 (Craig et al., 1984; Shin et al., 2015). 청소년은 성인과 달리 부모와 교사 등에 더 많이 의존하며, 이들에 의하여 양육과 교육 등이 이루 어지기에 더 높은 수준으로 외적 통제소가 나타난 것으로 생각된 다. 이와 더불어 국내 말더듬성인과 청소년 모두 해외 결과보다 높 은 패턴을 보였기에 이후 연구에서는 국내의 특성을 보다 적절히 나타내는 통제소 관련 평가도구를 개발할 필요가 있을 것이다.

\section{제한점 및 제언}

본 연구의 제한점은 다음과 같다. 우선 대상자와 관련된 제한점 으로 인해 본 연구 결과를 일반화하는 데 어려움이 있을 수 있다. 예를 들어 본 연구에서는 상대적으로 적은 수의, 남자 중학생과 고 등학생만을 대상으로 연구를 진행하였다. 청소년 시기에는 신체와 사고, 인지 등이 빠르게 발달하는 시기이기에 후속연구에서는 중 학생 그룹, 고등학생 그룹으로 나누어 연령 집단 별로 차이가 나타 나는지 살펴보는 것이 필요할 것이다. 더불어 성에 따라서 인과소 의 양상에 차이가 나타날 수 있기에(Lee, 2013), 후속 연구에서는 말더듬 여학생의 특성을 살펴볼 필요가 있다. 또한 앞서 기술하였 듯이 본 연구의 말더듬청소년 참여자들은 모두 치료경험이 있었다. 또한 모두 현재 치료를 받는 중이었으나 이러한 치료경험과 관련된 통제를 본 연구에서는 실시하지 않았다. 이러한 치료경험이 인과소 결과에 영향을 끼칠 수 있기에 후속 연구에서는 과거 및 현재의 치 료경험을 통제한 상태에서의 말더듬청소년과 일반청소년과의 비 교 연구가 필요하며, 치료 중 변화를 의사소통 인과소 평가도구가 적절히 나타낼 수 있는지 살펴볼 필요가 있다.

본 연구에서는 의사소통 관련 인과소와 다른 말더듬 내적 특성 과의 상관관계만을 살펴보았으나 후속 연구에서는 불안정도, 학업 성적 등과 같은 다른 전반적인 특성과의 상관관계를 살펴보는 것이 필요할 것이다. 이와 같은 보다 일반적인 특성과의 상관관계 분석 을 통하여 말더듬이 청소년에게 끼치는 영향을 보다 넓은 관점에 
서 분석할 수 있을 것이다.

특히 말더듬청소년의 내적 특성은 평가방법 등에 따라서 달리 나타날 수 있기에 말더듬청소년을 효율적으로 중재하기 위해서는 다양한 방식으로 이들을 평가하는 것이 필요하다는 점이 강조된 다. 전술하였듯이 자유롭게 작성한 글의 내용분석이 대상자의 특 성을 민감하고 타당하게 나타낼 수는 있으나 이러한 내용분석을 적절히 사용하기에는 어려움이 있을 수 있다. 이와 같은 어려움으 로 인하여 본 연구에서는 상대적으로 소수의, 제한된 항목으로 이 루어진 의사소통 관련 인과소 평가도구를 사용하여 말더듬청소년 의 인과소를 측정한 결과, 이와 같은 제한된 평가도구가 말더듬청 소년의 특성을 적절히 나타낼 수 있음을 보고하였다. 하지만 이와 더불어 치료경험 등의 개별적인 특성을 고려한 해석이 중요할 수 있다는 점 역시 본 연구에서는 지적되었다. 이와 더불어 단순히 해 외의 평가도구를 사용하는 것 역시 제한점이 있을 수 있다는 점 역 시 지적되었다. 이와같은 점을 고려해볼 때 말더듬청소년에게 적절 한 중재를 제공하기 위해서 언어치료사는 공식적, 비공식적 평가도 구를 각 치료대상자에게 맞게 적절히 선택하여 실시하고 이를 다 른 요소들을 고려하여 종합적으로 해석할 수 있는 능력을 배양시 키는 것이 중요할 것이다. 이러한 치료 중 변화의 기초적인 평가도구 로 임상가는 본 연구에서 개발한 의사소통 인과소 평가도구를 사 용할 수 있을 것이다. 또한 이러한 설문지 형식의 평가도구와 더불 어 임상가는 내용분석을 통한 보다 심화된, 그리고 개별화된 평가 를 진행할 수 있을 것이다. 내용분석을 통한 인과소 측정의 경우, 대 상자의 “말과 인식”에 보다 더 집중할 수 있는 방식을 제공하기에 보다 더 개별화된 평가와 중재를 가능하게 할 수 있을 것이다. 이러 한 결과 등을 종합하여 임상가는 각 대상자의 변화 추이를 보다 심 도깊게 개별적으로 측정할 수 있을 것이다. 이는 특히 모든 대상자 가 “오리진의 증가와 폰의 감소”와 같은 바람직한 혹은 기대되는 변 화양상을 보이지 않기 때문에 더욱 중요할 수 있을 것이다(Lee et al., 2011, 2015). 예를 들어 대상자는 치료를 통하여 개별적인 성향 의 특성, 유창성 증진을 위한 기법사용의 중요성 인지 등을 통하여 오리진의 감소 혹은 폰의 증가를 보일 수 있으며, 때로는 외적 통제 소의 증가 등을 보일 수 있을 것이다(De Nil \& Kroll, 1995; Lee et al., 2011, 2015). 이러한 개별적이고도 다양한 변화추이를 임상가는 적절한 평가도구를 사용하여 측정하고 이에 따라 중재목표를 수정 할 수 있어야 할 것이다.

\section{결론}

말더듬청소년을 대상으로 의사소통과 관련된 인과소를 간편하 게 측정할 수 있는 설문지 형식의 평가도구로 측정한 결과, 말더듬
청소년은 일반청소년보다 높은 오리진과 폰 점수를 보였다. 더불어 내용분석을 이용하여 오리진과 폰을 측정한 결과, 말더듬청소년의 폰 점수가 일반청소년보다 유의하게 높았다. 이러한 결과는 말더듬 청소년은 말더듬성인과 유사한 심리적 특성을 보인다는 점을 시사 한다. 이에 이들을 대상으로 한 치료는 보다 이들의 주체적인 특성 을 향상시키는 것을 목표로 한 치료가 필요할 것이다.

\section{REFERENCES}

Blood, G. W., \& Blood, I. M. (2004). Bullying in adolescents who stutter: communicative competence and self-esteem. Contemporary Issues in Communication Science and Disorders, 31, 69-79.

Craig, A. R., Franklin, J. A., \& Andrews, G. (1984). A scale to measure locus of control of behaviour. British Journal of Medical Psychology, 57, 173-180.

De Charms, R. (1968). Personal causation: the internal affective determinants of behavior. London: Academic Press.

De Nil, L. F., \& Kroll, R. M. (1995). The relationship between locus of control and long-term stuttering treatment outcome in adult stutterers. Journal of Fluency Disorders, 20, 345-364.

DiLollo, A., Neimeyer, R. A., \& Manning, W. H. (2002). A personal construct psychology view of relapse: indications for a narrative therapy component to stuttering treatment. Journal of Fluency Disorders, 27, 19-42.

Gottschalk, L. A., \& Gleser, G. C. (1969). The measurement of psychological states through the content analysis of verbal behavior. Berkeley, CA: University of California Press.

Guitar, B. (2013). Stuttering: an integrated approach to its nature and treatment (4th ed.). Philadelphia, PA: Lippincott Williams \& Wilkins.

Guitar, B., \& McCauley, R. (2010). Treatment of stuttering: established and emerging interventions. Baltimore, MD: Lippincott Williams \& Wilkins.

Hugh-Jones, S., \& Smith, P. K. (1999). Self-reports of short-and long-term effects of bullying on children who stammer. British Journal of Educational Psychology, 69, 141-158.

Lee, H., Lee, S., Sim, H., \& Oh, I. (2016). A qualitative study of exploring bullying experiences of adolescents who stutter. Secondary Education Research, $64,417-450$.

Lee, K. (2013). Locus of causality differences in the writings of university students according to gender and topics of writing. Communication Sciences « Disorders, 18, 116-126.

Lee, K., Manning, W. H., \& Herder, C. (2011). Documenting changes in adult speakers' locus of causality during stuttering treatment using Origin and 
Pawn scaling. Journal of Fluency Disorders, 36, 231-245.

Lee, K., Manning, W. H., \& Herder, C. (2015). Origin and pawn scaling for adults who do and do not stutter: a preliminary comparison. Journal of Fluency Disorders, 45, 73-81.

Manning, W. H. (2010). Clinical decision making in fluency disorders (3rd ed.). Clifton Park, NY: Delmar Cengage Learning.

McAllister, J., Collier, J., \& Shepstone, L. (2012). The impact of adolescent stuttering on educational and employment outcomes: evidence from a birth cohort study. Journal of Fluency Disorders, 37, 106-121.

O’Brian, S., Jones, M., Packman, A., Menzies, R., \& Onslow, M. (2011). Stuttering severity and educational attainment. Journal of Fluency Disorders, $36,86-92$.

Plimpton, F., \& de Charms, R. (1976). Origins and pawns in the classroom. In R. de Charms (Ed.). Enhancing motivation: changes in classroom (pp. 112-140). New York, Irvington Publishers.

Rotter, J. B. (1966). Generalized expectancies for internal versus external control of reinforcement. Psychological Monographs: General and Applied, 80, $1-28$.

Shin, M., \& Lee, K. (2013). Communication-related and general locus of cau- sality of male adults who stutter. Communication Sciences \& Disorders, 19, 238-248.

Shin, M., Chon, H., \& Lee, S. (2009). A review of recent trends in stuttering treatment research. Korean Journal of Communication Disorders, 14, 531562.

Shin, M., Lee, K., \& Sung, J. A. (2015). Locus of causality comparison of male adults who do and do not stutter. Communication Sciences \& Disorders, 20, 596-606.

Sim, H. S., Shin, M. J., \& Lee, E. J. (2010). Paradise-Fluency Assessment II. Seoul: Paradise Welfare Foundation.

Westbrook, M. T., \& Viney, L. L. (1980). Scales measuring people’s perception of themselves as origins and pawns. Journal of Personality Assessment, 44, 167-174.

Williams, D. E., Melrose, B. M., \& Woods, C. L. (1969). The relationship between stuttering and academic achievement in children. Journal of Communication Disorders, 2, 87-98.

Yaruss, J. S., \& Quesal, R. W. (2004). Stuttering and the International Classification of Functioning, Disability, and Health (ICF): an update. Journal of Communication Disorders, 37, 35-52. 
Appendix 1. 의사소통 인과소 평가도구

방법: 본 검사는 말에 대해서 어떠한 생각을 하고 있는지 살펴보는 것을 목표로 합니다. 각 문항에 정답이나 오답은 없으며 본인이 각 문항에 대해서 어떻게 생각하는지, 혹은 각 문항이 평상시의 자신의 행동과 얼마나 일치하는지 ( ) 안에 숫자로 표시해 주세요. 모든 질문에 답해주세요.

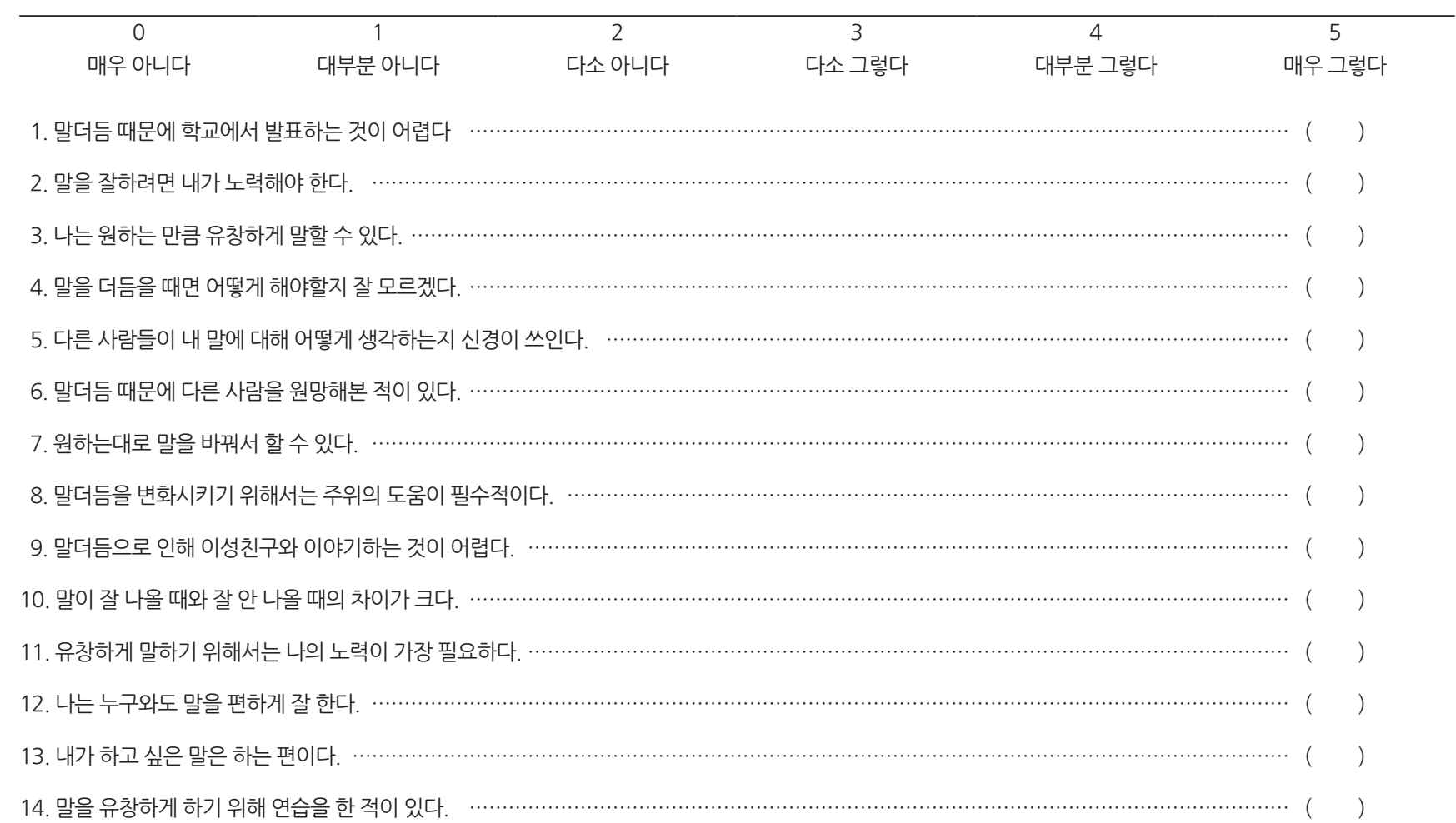




\section{국문초록}

\section{말더듬청소년을 대상으로 한 의사소통 관련 인과소 평가도구 기초 연구 이경재}

대구가톨릭대학교 언어청각치료학과

배경 및 목적: 말더듬청소년은 학업적, 신체적, 정신적 특성 등으로 인하여 치료가 어려울 수 있으나 아직 국내에서 이들을 대상으로 하는 평가도구는 부족한 편이다. 이에 치료 중 변화를 민감하고 타당하게 측정할 수 있는 설문지 형식의 인과소 평가도구를 개발하고 말더듬청소년과 일반청소년의 인과소를 비롯한 다양한 특성을 비교하고자 하였다. 방법: 본 연구에서는 총 18 명의 말더듬청소년과 일 반청소년을 대상으로 설문지 형식의 의사소통 인과소 평가도구를 사용하여 오리진과 폰을 측정하였다. 더불어 의사소통 관련 인과소 와 일반적인 상황에서의 인과소를 내용분석을 통하여 측정하였다. 이외에 통제소와 의사소통태도 평가 등을 실시하였다. 결과: 설문지 형식의 의사소통 인과소 평가 결과, 말더듬청소년은 일반청소년보다 높은 오리진과 폰 점수를 보였다. 더불어 말더듬청소년의 의사소 통 관련 폰 점수는 일반청소년보다 높았다. 더불어 설문지 형식의 인과소 평가 결과는 행동통제소, 의사소통태도 평가 결과 등과 유의 한 상관관계를 보였다. 논의 및 결론: 본 연구는 제한된 항목으로 이루어진 의사소통 인과소 평가도구가 타당하고 신뢰롭게 말더듬청 소년의 특성을 나타낼 수 있다는 점을 시사한다. 더불어 말더듬청소년은 말더듬성인과 유사한 특성을 보이기는 하지만 이들을 대상으 로 보다 효율적인 치료를 제공하기 위해서는 이들의 특성을 보다 면밀히 살펴보는 것이 필요하다는 점을 강조한다.

핵심어: 말더듬, 말더듬청소년, 오리진, 폰, 인과소

이 논문 또는 저서는 2015년 대한민국 교육부와 한국연구재단의 지원을 받아 수행된 연구임(NRF-2015S1A5A8017349).

\section{참고문헌}

신문자, 이경재(2014). 말더듬성인남성의 의사소통 상황과 일반적인 상황 관련 글쓰기에서의 인과소 비교. 언어청각장애연구, 19, 238-248.

신문자, 이경재, 성진아(2015). 말더듬성인 남성과 일반성인 남성의 인과소 비교. 언어청각장애연구, 20, 596-606.

신문자, 전희정, 이수복(2009). 유창성장애 연구의 최근 동향: 치료를 중심으로. 언어청각장애연구, 14, 531-562.

심현섭, 신문자, 이은주(2010). 파라다이스 유창성 검사 II. 서울: 파라다이스 복지재단.

이경재(2013). 일반 대학생의 글쓰기 분석을 통한 성별과 주제에 따른 인과소차이. 언어청각장애연구, 18, 116-126.

이현경, 이수복, 심현섭, 오인수(2016). 말더듬 청소년의 괴롭힘(bullying)에 관한 질적연구. 중등교육연구, 64, 417-450. 